\title{
35. The third attempt at the electric car might be the successful one Geoffrey Heal
}

Battery electric vehicles (BEVs) have lost the fight with internal combustion engines (ICEs) twice - once at the beginning of the twentieth century, when both ICE vehicles and BEVs competed, and also again at the end of that century, when General Motors released its EV1 in 1996, only to pull it from the market in 1999. In 2003, Elon Musk and partners bet on the BEV for a third time, and so far, this third bet has proven lucky.

In 2006, Musk set out his business plan:

- build sports car;

- use that money to build an affordable car;

- use that money to build an even more affordable car;

- while doing above, also provide zero-emission electric power-generation options.

The really smart part of this was to start by building a sports car and then the Tesla Model S, both of which could be sold to the high end of the market where buyers were not price sensitive and where the novelty and environmental friendliness of an electric vehicle was a major selling point. Rich environmental buyers would happily spend the extra for a Tesla Roadster or Model S, generating the cash that would fund the development of less expensive vehicles such as the Model 3 and Model Y. In the process, Musk and Tesla transformed EVs from utilitarian to aspirational vehicles.

Musk is a larger-than-life character, self-confident and abrasive, a successful serial entrepreneur who is seeking to revolutionize transport both on Earth and in space. Musk's earlier ventures included co-founding PayPal and Zip2, an internet mapping company: sale of these provided some of the capital to start Tesla. He co-founded Tesla and founded and owns SpaceX, the most successful commercial launcher of space rockets. SpaceX has reduced the cost of launching satellites into orbit by about 90 percent, largely by pioneering the use of reusable rockets.

Tesla states that its mission is to "accelerate the world's transition to a sustainable future," and is working on this by producing BEVs and solar 
cells for electric power generation. Musk commented in an interview in 2017 that "my original interest in electric cars and solar energy, which goes back to when I was in university, was not based on environmental concern, it was based on sustainability, in the sense of ensuring that civilization can continue to progress" (Smith, 2017). This theme recurs in his comments about SpaceX: Musk wants to colonize planets to ensure the survival of the human race. He feels that we may do irreparable harm to Earth.

Musk personifies Tesla: when there is a major announcement, the launch of a new product, Musk appears on stage alone. As far as the public is concerned, there is no one else senior at Tesla. This monopolizing the limelight is perhaps connected with the high turnover of senior management at Tesla: Tesla lost 44 percent of Musk's direct reports in a nine-month period in comparison with 9 percent at other high-profile Silicon Valley companies (Mitchell, 2020).

Tesla went public in 2010 and since then its market capitalization has fluctuated widely, reaching as high as $\$ 400$ billion, at which point it was the most valuable car company in the US or the EU, in spite of producing fewer than half a million vehicles annually. For comparison, GM, VW and Toyota produce in the order of 10 million cars per year.

Betting on a company making only BEVs in 2003 was risky in the extreme. At that point, lithium-ion batteries cost over $\$ 1000$ per $\mathrm{kWh}$, and the Tesla Model S uses an $80 \mathrm{kWh}$ battery - bigger in the long-range version. At 2003 prices, the battery alone would have cost $\$ 80000$ ! It's no wonder that BEVs were not taken seriously then. Today, Tesla claims to buy its battery packs for about $\$ 100$ per $\mathrm{kWh}$, so the battery is under $\$ 10000$. Tesla has played a major role in reducing battery prices, benefiting its competitors as well as itself. There are other risks associated with focusing on the lithium-ion battery technology: it could be replaced by hydrogen fuel cells or even by supercapacitors, which are used successfully in hybrid racing vehicles. It is still too early to know what electric vehicle technology will look like ten years from now.

Musk has not yet achieved one key point on his famous four-bullet-point business plan (see above): Tesla has not yet produced "an even more affordable car." To be fair, the Model 3 is more affordable than the Model S, but the least expensive version is listed on Tesla's website at $\$ 33690$, including potential tax incentives and fuel savings of $\$ 6300$. So, the cash cost is over $\$ 40000$. The mid-range versions of the Model 3 cost just under $\$ 50000$. According to the Kelley Blue Book vehicle valuation and automotive research company, the average new car price in the US in May 2019 was $\$ 36718$, so the Model 3 is really not in the "affordable" segment of the market.

While Tesla is still a small company, with sales of under half a million units annually, it has had a profound impact on the automobile market. It has shown that BEVs can be cool and profitable, two facts that no car maker believed prior to the release of the Model S. This car received rave reviews from the automo- 
bile press and from bodies like Consumer Reports in the US, which ranked it as one of the best cars ever made. Their summary is that "The fully electric Model $\mathrm{S}$ is a remarkable car that combines performance, agility, styling, high-tech, no emissions and low operating costs. It's one of the best cars we've ever tested" (Consumer Reports, 2020). It rapidly took market share from Audi, BMW, Jaguar, Lexus and Mercedes in the top end of the automobile markets of the US, the EU and China, become the best-selling luxury car in the US, and was instrumental in forcing other high-end manufacturers to offer BEVs in competition with the Model S. Tesla's Model 3 has now replaced the Model S as the best-selling luxury car in the US. Without Musk's audacious bet in 2003, there probably wouldn't be electric vehicles today.

\section{REFERENCES}

Consumer Reports (2020), “Tesla Model S”, 2020, accessed March 2, 2020 at https:// www.consumerreports.org/cars/tesla/model-s/2020/overview/.

Mitchell, R. (2017), "If Elon Musk is your boss, get your resume ready," The Telegraph, May 24, accessed March 2, 2020 at https:/www.latimes.com/business/ story/2019-08-15/elon-musk-tesla-executive-turnover.

Smith, A. (2017), "Who is Elon Musk? Tech billionaire, SpaceX cowboy, Tesla pioneer - and real life Iron Man," The Telegraph, May 24, accessed August 26, 2020 at https://www.telegraph.co.uk/technology/0/elon-musk-tech-billionaire-spacex -cowboy-real-life-iron-man/. 